\title{
Development and Evaluation of PCR-Based Diagnostic Assays for the Bacterial Speck and Bacterial Spot Pathogens of Tomato
}

\author{
Diane A. Cuppels, Agriculture and Agri-Food Canada, London, ON, N5V 4T3 Canada; Frank J. Louws, Depart- \\ ment of Plant Pathology, North Carolina State University, Raleigh 27695; and Teresa Ainsworth, Agriculture and \\ Agri-Food Canada, London, Canada
}

\begin{abstract}
Cuppels, D. A., Louws, F. J., and Ainsworth, T. 2006. Development and evaluation of PCRbased diagnostic assays for the bacterial speck and bacterial spot pathogens of tomato. Plant Dis. 90:451-458.

Bacterial speck and bacterial spot lesions can easily be confused with each other and with those formed by other tomato pathogens. To facilitate disease diagnosis, we developed and evaluated polymerase chain reaction (PCR)-based lesion assays using crude DNA extracts and primer sets COR1/2 (bacterial speck) and BSX1/2 (bacterial spot). All 29 pathogenic Pseudomonas syringae pv. tomato strains tested produced a 689-bp amplicon with COR1/2; 28 of the 37 geographically diverse bacterial spot-causing xanthomonad (BSX) strains that were tested generated the 579-bp BSX1/2 amplicon. The detection limit with plant samples was 30 to $50 \mathrm{CFU} /$ reaction. In a 6year study, the COR1/2 PCR assay diverged from the culture-based classical assay for only 3 of 70 bacterial speck lesion samples collected from Ontario greenhouses and tomato fields; the BSX1/2 assay was positive for 112 of the 124 confirmed bacterial spot lesions sampled. The majority $(66 \%)$ of the BSX strains isolated from these lesions belonged to group D; the 12 strains that were BSX1/2-negative belonged to group C. Group D strains produced a 425-bp PCR product with crude DNA extracts but a 579-bp product with purified DNA; the former was identical to the latter except that it was missing $150 \mathrm{bp}$ from the middle of the 579-bp sequence.
\end{abstract}

Additional keywords: coronatine, rep-PCR, Xanthomonas gardneri

Bacterial speck, caused by Pseudomonas syringae pv. tomato (Okabe) Alstatt, and bacterial spot, caused by Xanthomonas axonopodis pv. vesicatoria (groups $\mathrm{A}$ and C), X. vesicatoria (group B) and ' $X$. gardneri' (group D) (groups A and B formerly were known as $X$. campestris pv. vesicatoria (Doidge 1920) Dye 1978b), are two of the more persistent and economically important bacterial diseases of tomato ( $L y$ copersicon esculentum Mill.) in North America. Although the most conspicuous symptoms for both diseases are lesions on the foliage and fruit, all aboveground parts of the tomato plant are susceptible to infection. When environmental conditions are optimal for disease development, yield losses can be severe $(17,25)$. Although several commercial cultivars carry resistance to bacterial speck, none are resistant to all known races of the bacterial spot pathogen. Thus, current disease manage-

Corresponding author: D. A. Cuppels

E-mail: cuppelsd@em.agr.ca

GenBank accession numbers U33313 and AY914087.

Accepted for publication 7 November 2005.

DOI: 10.1094/PD-90-0451

Department of Agriculture and Agri-Food, Government of Canada. () Minister of Public Works and Government Services Canada 2006 ment strategies include vigorous spray programs with bacterial management products such as copper or acibenzolar-Smethyl (Actigard) in combination with the foliar fungicides (e.g., chlorothalonil, mancozeb, and strobilurins), field sanitation, crop rotation, and the use of pathogen-free planting material.

Because bacterial speck and bacterial spot lesions on the foliage of field tomato plants can vary in size, texture, and color, they easily are confused with each other and with those formed by other tomato pathogens and abiotic disorders. Although culture-based methods still are widely used for diagnosis of these bacterial diseases, they are time consuming and do not provide the sensitivity and specificity of nucleic acid-based methods (15). TPR1, which is a $5.3-\mathrm{kb}$ fragment of the $P$. syringae pv. tomato strain DC3000 gene cluster controlling production of the phytotoxin coronatine, is an effective diagnostic probe for bacterial speck when used in colony blot assays with the semiselective VogelBonner-tartrate (VBTar) medium (13). Likewise, KK1750 (22), an X. vesicatoria strain DC93-1 sequence (1.8-kb) of unknown function, has been used in combination with the semiselective Chang Kama Tween medium (CKTM; 40) to screen for the bacterial spot pathogen in tomato and pepper samples. The major drawback to these probe-based procedures is that they take 4 to 5 days to complete.
Bacterial spot disease diagnosis is complicated further by the heterogeneity of the xanthomonad strains that cause this disease (7). The nomenclature of xanthomonads, including those pathogenic on tomato, has been debated $(37,44,46)$, but an enhanced understanding of the systematics of the tomato pathogens is emerging $(20,21,33,44)$. Recent work has shown that there are at least four distinct phenotypic groups, A, B, C, and D (19). Groups A and B are genotypically distinct $(24,41,44)$ and, thus, Vauterin et al. classified them as $X$. axonopodis pv. vesicatoria and $X$. vesicatoria, respectively. Group $\mathrm{C}$ strains are related to but distinct from group A strains, whereas group D strains are phenotypically and genotypically distinct from the other three groups $(8,19)$. Group D strains also are referred to as 'Xanthomonas gardneri' strains. A recent publication has proposed the following renaming: group $\mathrm{A}$ strains as $X$. euvesicatoria, group $C$ strains as $X$. perforans, and Group D strains as $X$. gardneri; group B strains remain as $X$. vesicatoria (20). To date, no DNA sequence has been identified that is unique to all the bacterial spot-causing xanthomonads (BSX). In earlier work, probe KK1750 hybridized to $89 \%$ of the 46 BSX strains tested; unfortunately, however, no group C strains and only one group D strain were included in that survey (22). Obradovic et al. have designed a set of primers for the bacterial spot pathogen based on an hrp sequence that is highly conserved among the pathogenic xanthomonads; restriction enzyme analysis of the amplicon produced with these primers has been used to differentiate the four BSX groups (31). If used without restriction enzyme analysis of the amplicon, these primers do not distinguish BSX strains from xanthomonads pathogenic on other hosts. Primers specific for the fimA sequence of $X$. campestris pv. vesicatoria also have been designed, but they detect only $X$. vesicatoria (group B) strains (43).

The objectives of the present study were to design and evaluate polymerase chain reaction (PCR)-based diagnostic assays for bacterial speck and bacterial spot. The PCR primer sets were based on the DNA probes TPRI and KK1750, because both sequences had been used successfully for several years to diagnose bacterial diseases on Ontario field tomato plants. In the course of this work, we tested DNA ex- 
tracts from 52 strains of $P$. syringae, 36 BSX strains, 36 strains of non-BSX pathogenic xanthomonads, 6 strains of nonpathogenic epiphytic xanthomonads, and 10 strains of other plant-associated bacteria for the ability to act as template for primers COR1/2 (bacterial speck) and BSX1/2 (bacterial spot). As a positive control, we used the primer set derived from a conserved $h r p$ sequence described above, RST65/69 (31). We also performed an extensive survey of diseased samples from transplant greenhouses and from Ontario tomato fields to determine the effectiveness of primer sets COR $1 / 2$ and BSX1/2 as diagnostic tools. Using repetitive sequence-based (rep)-PCR, restriction enzyme analysis of the RST65/69 amplicon, and physiological and pathogenicity testing, we found that the majority of the BSX strains isolated from Ontario tomato fields since 2000 were group D, or X. gardneri, strains; all of these strains were positive with the BSX1/2 primer set and hybridized to our DNA probe KK17750. A few group C strains also were found; they hybridized to the probe but not all of them produced a product with the BSX1/2 primers.

\section{MATERIALS AND METHODS}

Bacterial strains and growth conditions. The plant-associated bacterial strains used in this study are listed in Table 1. Bacteria were grown on nutrient broth yeast extract (NBY; 14) agar, CKTM (a semiselective medium for the bacterial spot pathogen; 40) or VBTar agar (a semiselective medium for the bacterial speck pathogen; 14) for 24 to $48 \mathrm{~h}$ at $25^{\circ} \mathrm{C}$. All strains were stored at $-72^{\circ} \mathrm{C}$ in NBY broth containing $15 \%$ glycerol.

Isolation and manipulation of bacterial DNA. Unless described below, the procedures used to extract, purify, and manipulate DNA were performed as described previously $(3,36)$. Bacterial genomic DNA was purified using a Qiagen Genomic-tip System (Qiagen Inc., Chatsworth, CA), whereas PCR products were cloned using the Qiagen PCR cloning kit (Qiagen Inc.). A 100-bp DNA ladder (Invitrogen Canada Inc., Burlington, ON, Canada) was used as a molecular size standard for agarose gels.

Table 1. Polymerase chain reaction (PCR) results for the bacterial strains used in this study

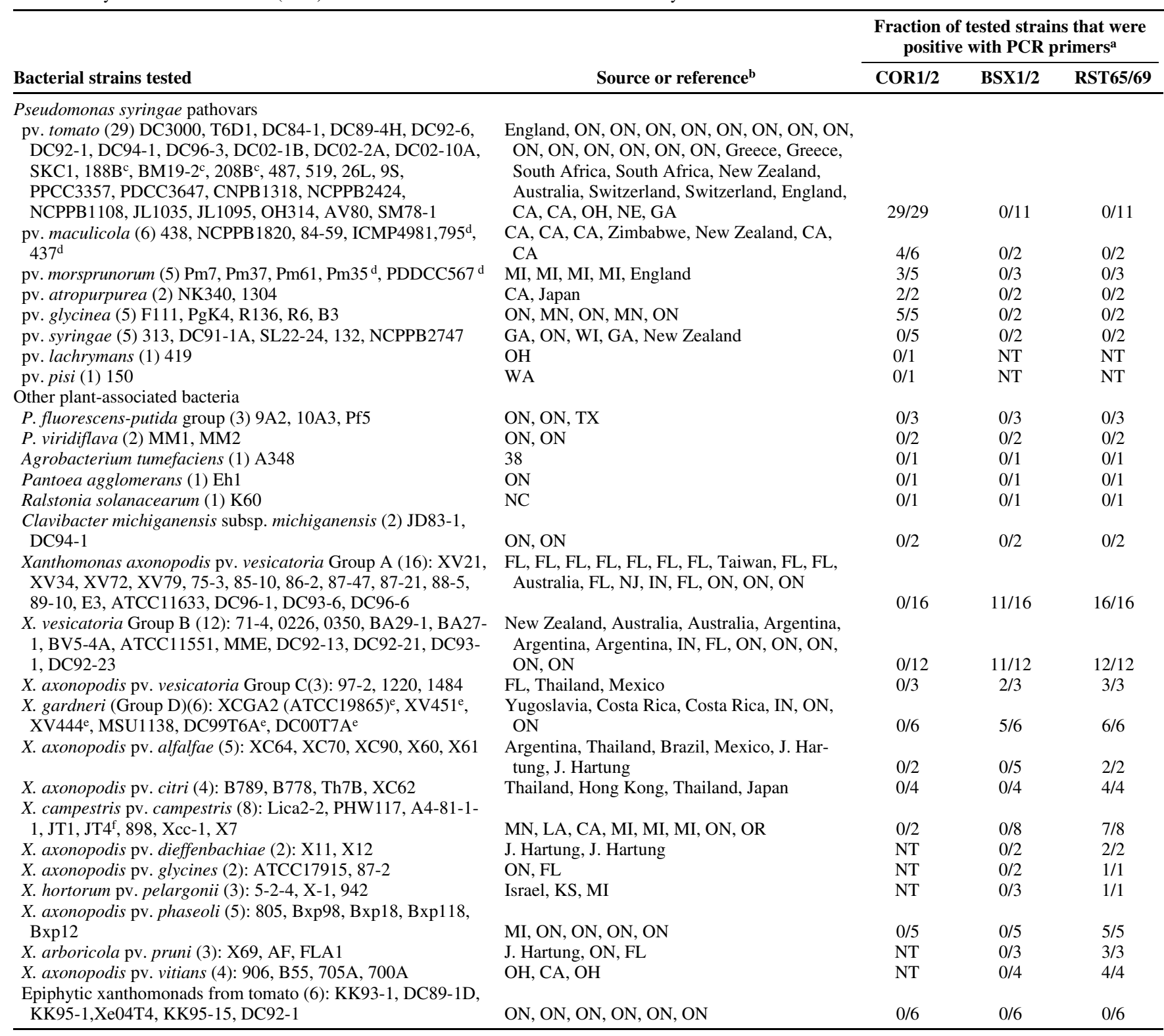

\footnotetext{
${ }^{a}$ Each PCR assay was performed a minimum of three times; NT = not tested.

${ }^{\mathrm{b}}$ Where sources (geographic origins) were in North America, the state or province abbreviation is given.

${ }^{\mathrm{c}}$ Strains belonging to race 1 of $P$. syringae pv. tomato.

${ }^{\mathrm{d}}$ Strains not producing coronatine or giving a PCR product.

${ }^{\mathrm{e}}$ The BSX PCR product with these strains was $425 \mathrm{bp}$, rather than the $579 \mathrm{bp}$ characteristic of other BSX strains.

${ }^{\mathrm{f}}$ Strains not giving a PCR product with the RST primers.
} 
Cloning and sequencing of bacterial DNA. The bacterial speck probe TPRI, derived from the coronatine gene cluster of P. syringae pv. tomato DC3000 (14), was cloned and sequenced in order to design PCR primers. A $1.5-\mathrm{kb}$ Pst I fragment of TPRI was cloned into pBluescript II KS+ (Stratagene, La Jolla, CA; 39) by methods described previously $(14,27)$. It was sequenced using the dideoxynucleotide chain termination method and the Taq DyeDeoxy Terminator Cycle sequencing kit (Applied Biosystems, Foster City, CA) by the Core Facility for Protein/DNA Chemistry at Queen's University, Kingston, ON, Canada (GenBank accession number U33313). Based on a search of the National Center for Biotechnology Information (NCBI) databases using the BLAST algorithm (1), the sequence is a homolog of the $P$. syringae pv. glycinea PG4180 cfa7 gene (AF098795) (34), which is part of the gene cluster controlling production of the coronatine component coronafacic acid (9).

The bacterial spot DNA probe KK1750 was a 1.8-kb PstI-NotI fragment of genomic DNA from $X$. vesicatoria DC93-1 identified by genomic subtraction (22). It was cloned into pBluescript II KS+ and sequenced as described above (GenBank accession number AY914087). When a search of the NCBI databases was performed, the first $478 \mathrm{bp}$ of one end of this sequence had $95 \%$ similarity to a portion of a putative truncated transposase in the region downstream of $h r p A$ from $X$. campestris pv. vesicatoria 85-10 (16), but no homologs could be found for the remainder of this sequence.

PCR products that had been obtained using primer set BSX1/2 (see below) and crude BSX DNA extracts as template were purified using the Qiagen PCR Purification kit (Qiagen Inc.). They were cloned into the pDrive vector supplied with the Qiagen PCR Cloning kit (Qiagen Inc.) according to the instructions of the manufacturer. Commencing at the T7 and SP6 primer sites on the pDrive vector, the cloned BSX DNA was sequenced with the Applied Biosystems (ABI) PRISM BigDye Terminator Cycle Sequencing Kit (PE Biosystems, Mississauga, ON, Canada) and an ABI 377 DNA sequencer housed at the Agriculture and Agri-Food Canada Southern Crop Protection and Food Research Centre in London, ON, Canada. Multiple alignments of the various cloned BSX sequences were generated using MEGALIGN (version 5.07; DNASTAR Inc., Madison, WI) and the CLUSTAL V method. The output was formatted for printing using BOXSHADE version 3.21.

Oligonucleotide primers. The PCR primers used in this study were selected using the Oligo Primer Analysis Software (version 5; Molecular Biology Insights, Inc., Cascade, CO) and synthesized by Invitrogen Canada, Inc. The PCR primers for bacterial speck were selected from the $1.5-\mathrm{kb}$ sequence of the bacterial speck probe TPRI: COR1, 5' GGA CTC AGC AGT ATC ATC TCG GGA CG 3'; COR2, 5' TGC AGG GTC TTG GGG AGC ACG $3^{\prime}$. Two sets of primers were used for bacterial spot. One set was derived from that portion of the $1.8-\mathrm{kb}$ KK1750 sequence that did not contain the putative truncated transposase: BSX1, 5' TCG CCC ATA GTC ACC ATT GGA TAG ACC 3'; BSX2, 5' GCC TAC GCC GAG AAG TTA GCC ACC GAG 3'. The other primer set for bacterial spot was derived from the $h r p B$ operon of the hrp gene cluster of $X$. campestris pv. vesicatoria strain 75-3: RST65, 5' GTC GTC GTT ACG GCA AGG TGG TCG 3'; RST69, 5' TCG CCC AGC GTC ATC AGG CCA TC 3' (31).

PCR. Amplification was performed in 0.2-ml thin-walled PCR tubes in a GeneAmp PCR System 9700 thermal cycler (Applied Biosystems, Foster City, CA). The final $25-\mu \mathrm{l}$ reaction mixture contained 1× PCR buffer, $2.0 \mathrm{mM} \mathrm{MgCl} 2,0.2 \mathrm{mM}$ each dATP, dCTP, dGTP, and dTTP, $1 \mu \mathrm{M}$ each primer, and $0.63 \mathrm{U}$ of Taq polymerase (New England Biolabs, Ltd., Pickering, ON, Canada). The following PCR protocol was used with the bacterial speck primers COR1/2: one cycle at $94^{\circ} \mathrm{C}$ for $2 \mathrm{~min} ; 40$ cycles of $30 \mathrm{~s}$ at $94^{\circ} \mathrm{C}, 45 \mathrm{~s}$ at $61^{\circ} \mathrm{C}$. and 30 s at $72^{\circ} \mathrm{C}$; and finally one cycle at $72^{\circ} \mathrm{C}$ for $5 \mathrm{~min}$. The PCR protocol for both sets of bacterial spot primers was the following: one cycle at $95^{\circ} \mathrm{C}$ for $2 \mathrm{~min}$; 40 cycles of $40 \mathrm{~s}$ at $95^{\circ} \mathrm{C}, 40 \mathrm{~s}$ at $63^{\circ} \mathrm{C}$, and $50 \mathrm{~s}$ at $72^{\circ} \mathrm{C}$; and finally one cycle at $72^{\circ} \mathrm{C}$ for 5 min. The PCR products $(5 \mu \mathrm{l})$ were loaded into $1.5 \%$ agarose gels in $0.5 \times \mathrm{TBE}$ (0.089M Tris-borate, $0.002 \mathrm{M}$ EDTA, $\mathrm{pH}$ 8.0) buffer for analysis. After electrophoresis for $2 \mathrm{~h}$ at $7.5 \mathrm{~V} / \mathrm{cm}$, the gels were stained with ethidium bromide $(1 \mu \mathrm{g} / \mathrm{ml})$ and digitally recorded. For the bacteria listed in Table 1, a minimum of two assays/primer set/strain were performed.

rep-PCR. Ontario BSX strains were characterized by rep-PCR using primers BOX, ERIC, and REP as described previously $(23,24)$. Fingerprint patterns were analyzed using GelCompar software (Applied Maths, Kortrijk, Belgium) and established library databases. A minimum of three rep-PCR gels were prepared for each strain-primer set.

Extraction of template DNA from bacterial colonies or plant material. Bacteria obtained by touching a pipette tip to a 24- to 48-h-old colony on NBY, VBTar, or CKTM agar were suspended in a nucleic acid extraction buffer (1\% Triton $\mathrm{X}-100,0.5 \%$ Tween $20,10 \mathrm{mM}$ Tris, 1 mM EDTA, pH 8.0; TTTE; 35) and subjected to a 3-min freezing in liquid nitrogen followed by a 5-min heating in a boiling water bath (freeze-boil method). After being chilled on ice for $5 \mathrm{~min}$, the tubes were centrifuged at maximum speed $\left(14,000 \times g, 4^{\circ} \mathrm{C}\right)$ to pellet any cellular debris. A sample of the supernatant then was added as template to the PCR master mix.

A similar procedure was used for extracting template DNA from tomato (or pepper) leaf and fruit lesions. A $25-\mathrm{mm}^{2}$ piece of tissue containing the lesion was excised from the plant sample, cut in quarters, and incubated on ice for $30 \mathrm{~min}$ in 0.2 $\mathrm{ml}$ of sterile water. The eluate then was centrifuged (maximum speed in a microfuge, $14,000 \times g$ ) and the pellet was suspended in TTTE and subjected to the freeze-boil treatment described above.

Screening diseased samples from seedling greenhouses and grower fields for the presence of bacterial speck and bacterial spot. Lesions were excised from diseased tissue samples from seedling greenhouses or grower fields as described above. After the 30-min incubation on ice, tissue was aseptically removed from the tube and the eluate was streaked on NBY, CKTM, and VBTar agar plates. The remainder of the eluate was centrifuged $\left(14,000 \times g, 4^{\circ} \mathrm{C}\right)$ and the pellet, after being resuspended in TTTE, was subjected to the freeze-boil treatment to produce a DNA template for the PCR assays. If $P$. syringae pv. tomato-like or BSX-like colonies developed on the agar plates, they were purified and stored at $-72^{\circ} \mathrm{C}$ in NBY broth plus $15 \%$ glycerol. These strains then were tested for pathogenicity on tomato and pepper plants (BSX colonies only). Crude DNA extracts of these strains (freeze-boil method) also were prepared and used as template in a PCR assay using the RST65/69 primers of Obradovic et al. (31).

Plant pathogenicity tests. All tests were performed in a plant growth chamber (CMP4030, Conviron, Winnipeg, Manitoba, Canada) with a 16 -h light $\left(25^{\circ} \mathrm{C}\right)$ and 8 -h dark $\left(22^{\circ} \mathrm{C}\right)$ cycle using 3 -week-old tomato seedlings (L. esculentum Mill. cv. Bonny Best) or 5-week-old pepper seedlings (Capsicum annuum L. cv. Merlin or Early Niagara Giant). Procedural details have been described previously $(10,22)$. Bacterial speck symptoms appeared within 4 to 7 days, whereas those of bacterial spot appeared within 7 to 14 days.

Tomato leaf bioassay for coronatine. Ethyl acetate extracts of bacterial cultures were tested for coronatine using a tomato leaf assay described previously (12). The assay was repeated three times for each strain.

Hybridization procedures. The procedures used for the preparation of dot blots and Southern blots have been described $(14,22)$. Dot blots were used to confirm the results of the PCR assays. The PCR reaction $(5 \mu \mathrm{l})$ was mixed with $45 \mu \mathrm{l}$ of TE buffer (10 mM Tris, $0.1 \mathrm{mM}$ EDTA, pH 8.0 ), boiled for $10 \mathrm{~min}$, chilled on ice, and then loaded into the well of a Milliblot apparatus (Millipore Corporation, Bedford, MA) onto a nylon membrane (Roche Diagnostics, Laval, Quebec, Canada). The 
bacterial speck probe was COR15, an amplified 1.5-kb PstI fragment of TPRI; the bacterial spot probe was BSX1323, an amplified 1.32-kb fragment of KK1750. The probes were labeled with digoxigenin (DIG-dUTP) (Roche Diagnostics) using the PCR DIG Probe Synthesis Kit (Roche Diagnostics).

Estimates of the detection limits for the bacterial speck and bacterial spot PCR assays. Three-week-old tomato seedlings (Lycopersicon esculentum Mill. cv. Bonny Best) were sprayed with a sterile water suspension of $P$. syringae pv. tomato T6D1 (rifampicin-resistant [Rif $\left.{ }^{\mathrm{r}}\right]$ ) at the following concentrations: $5 \times 10^{8} \mathrm{CFU} / \mathrm{ml}$ (three plants), $5 \times 10^{7} \mathrm{CFU} / \mathrm{ml}$ (three plants), $5 \times 10^{6} \mathrm{CFU} / \mathrm{ml}$ (three plants), and

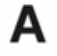

$\begin{array}{llllllll}M & 1 & 2 & 3 & 4 & 5 & 6 & 7\end{array}$

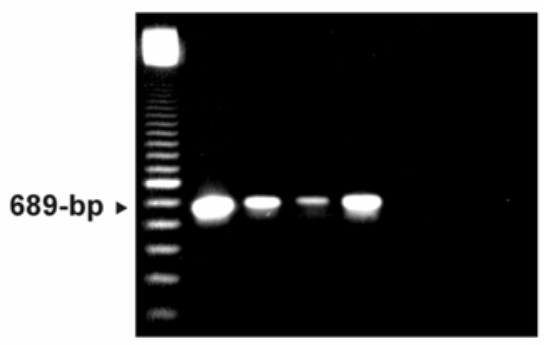

B

$\begin{array}{lllllll}M & 1 & 2 & 3 & 4 & 5 & 6\end{array}$

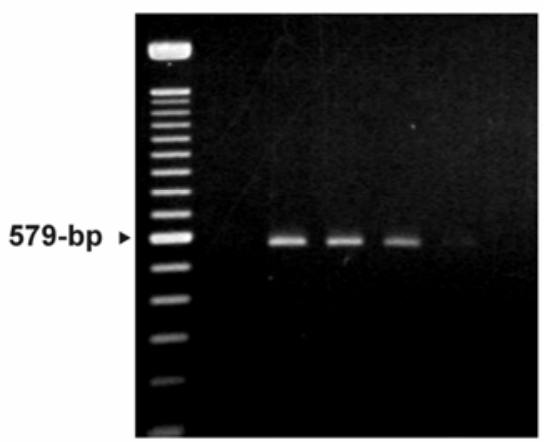

Fig. 1. Polymerase chain reaction (PCR) detection of A, Pseudomonas syringae pv. tomato and $\mathbf{B}$, Xanthomonas vesicatoria on inoculated but symptomless tomato leaves. Plant tissue samples were taken $4 \mathrm{~h}$ after spraying the plants with a suspension of $P$. syringae pv. tomato DCT6D1 or $X$. vesicatoria DC93-1. Before crude DNA was extracted from the sample for PCR, the number of viable bacteria/sample was determined using the semiselective media Vogel-Bonner-tartrate (for strain DCT6D1) or Chang Kama Tween medium (for strain DC931). A, Lane M, 100-bp ladder (Amersham Biosciences Corp., Piscataway, NJ); lane 1, positive PCR control, COR15 DNA; lanes 2 and 3, 100 bacteria/PCR reaction; lane $4,2,700$ bacteria/PCR reaction; lane 5-7, approximately 5 to 1 bacteria/PCR reaction. B, Lane M, 100-bp ladder (Invitrogen Canada, Inc.); lane 1, negative PCR control; lane 2, 40 bacteria/PCR reaction; lane 3, 400 bacteria/PCR reaction; lane 4, 300 bacteria/PCR reaction; lane 5, less than 1 bacteria/PCR reaction; lane 6 , approximately 3 bacteria/PCR reaction.
$1 \times 10^{6} \mathrm{CFU} / \mathrm{ml}$ (three plants). They were incubated at room temperature for $4 \mathrm{~h}$ and then a 10-by-5-mm tissue sample was excised from each plant and cut in half. One half was cut in quarters and placed in $100 \mu \mathrm{l}$ of TTTE; the other half was cut in quarters and placed in $1 \mathrm{ml}$ of $10 \mathrm{mM}$ potassium phosphate $(\mathrm{pH}$ 7.2) containing $0.1 \%$ Difco-peptone (KPP). After a 30-min incubation on ice, the leaf fragments were removed from both samples. The first sample was subjected to the freeze-boil treatment while the second sample was serially diluted and plated on NBY+ rif (50 $\mu \mathrm{g} / \mathrm{ml}$ ) agar. PCR assays were performed using the crude DNA extracts from the first sample. The experiment was performed in triplicate. The same procedure was used for determining the detection limit of the bacterial spot PCR assay; the strain used for these experiments was $X$. campestris pv. vesicatoria DC93-1 and the viable counts were determined on CKTM agar.

In a second set of experiments, the PCR detection limit was determined using DNA template extracted from tomato leaf wash water. Leaf samples were collected late in the season from a bacterial speck-infected (strain DCT6D1) tomato field plot (cv. Bonny Best; Agriculture and Agri-Food Canada farm, London, ON, Canada). Eight randomly collected 10 -g samples of symptomless leaves each were washed in 100 $\mathrm{ml}$ of sterile water and the wash water was processed as described previously to collect the leaf surface bacteria (13). The pellet was resuspended in $2 \mathrm{ml}$ of sterile water. A $100-\mu$ l aliquot of the suspension was subjected to the freeze-boil method to extract DNA template for PCR. Another aliquot then was serially diluted and plated on VBTar agar. Colony lifts of selected plates were hybridized to the DIG-labeled COR15 probe to determine viable cell counts (13)

Effect of field plant age and $P$. syringae pv. tomato population size on PCRbased detection. Leaves with bacterial speck-like lesions were collected throughout the growing season from several southern Ontario tomato fields. The samples were taken from the lower third of the plant. Each lesion was cut in half; one half was processed for PCR and the other half was macerated in $1 \mathrm{ml}$ of KPP. The macerate was serially diluted in KPP and aliquots of each dilution were spread on VBTar agar. After 3 days of incubation at $25^{\circ} \mathrm{C}$, colony lifts were prepared and processed as described previously (13).

\section{RESULTS}

Selection and specificity of primers for $P$. syringae pv. tomato and $X$. campestris pv. vesicatoria. The primers selected for the bacterial speck pathogen, COR $1 / 2$, amplified a 689-bp DNA segment from the presumed coronafacic acid biosynthesis gene $c f a 7$ of $P$. syringae pv. tomato DC3000. These primers were tested for specificity using purified genomic DNA from several plant-associated bacteria (Table 1). Amplicons of the expected size were produced with DNA extracts from all the coronatine-producing strains of $P$. $s y$ ringae tested, including pathovars tomato, maculicola, morsprunorum, atropurpurea, and glycinea. The two $P$. syringae pv. maculicola strains and two $P$. syringae pv. morsprunorum stains that did not exhibit amplification with COR $1 / 2$ also did not produce coronatine, as determined by the coronatine leaf bioassay. Likewise, no amplification occurred with DNA extracted from strains of noncoronatine-producing $P$. syringae pathovars and from strains of other plant-associated bacteria (Table 1).

The only xanthomonads or plantassociated bacteria that gave a positive response with the primers $\mathrm{BSX} 1 / 2$ were classified as $X$. axonopodis pv. vesicatoria (groups A and C), X. vesicatoria (group B), or ' $X$. gardneri' (group D) (Table 1). However, DNA from 8 of the $36 X$. campestris pv. vesicatoria strains tested, 5 group A (strains ATCC11633, 87-21, 88-5, 96-6, and 85-10), one group B (strain BA27-1), one group C (strain 1484), and one group D strain (strain MSU 1138), failed to act as template for these primers. Strain MSU1138 also did not hybridize with probe BSX1323. In addition to the strains listed in Table 1, the following strains were screened with the BSX and RST primers: $X$. axonopodis pv. vasculorum FB570, $X$. albilineans ATCC33915, X. campestris pv. armoraciae $071, X$. axonopodis pv. malvacearum X203, X. axonopodis pv. vignicola G-55, X. vasicola pv. holcicola X56, X. axonopodis pv. manihotis X40, X. campestris pv. raphani $69-2, X$. translucens pv. translucens ATCC19319, and X. axonopodis pv. begoniae JB1. The 579-bp BSX product was not formed with any of these strains; the 420-bp RST 65/69 product was produced with all strains except $X$. albilineans ATCC33915, X. vasicola pv. holcicola X56, X. axonopodis pv. malvacearum X203, and X. translucens pv. translucens ATCC19319.

PCR detection limit for plant-derived samples. Crude DNA extracts prepared from tissue samples of tomato transplant seedlings that had been sprayed with various concentrations of $P$. syringae pv. tomato DCT6D1 were used as templates for PCR amplification with the COR $1 / 2$ primers (Fig. 1A). The experiment was performed five times. Approximately $10^{4} \mathrm{CFU}$ of the bacterium on a $25-\mathrm{mm}^{2}$ square of leaf tissue were detected consistently after amplification and visualization using an agarose gel. The detection limit per reaction was approximately $1 \times 10^{2} \mathrm{CFU}$. At concentrations of approximately $10^{2} \mathrm{CFU}$ per $25 \mathrm{~mm}^{2}$ of leaf tissue, or 1 CFU/reaction, a 689-bp band appeared on the gel, but it was barely discernible. A similar experiment was performed with the BSX primers. Tissue extracts were pre- 
pared from tomato transplant seedlings that had been sprayed with various concentrations of $X$. vesicatoria strain DC93-1. The detection limit was similar: approximately $4 \times 10^{3} \mathrm{CFU}$ per $25 \mathrm{~mm}^{2}$ of leaf tissue or $4.0 \times 10^{1} \mathrm{CFU} /$ reaction (Fig. 1B).

The detection limit for PCR assays using DNA template extracted from tomato leaf wash water also was determined. In a field-based experiment, eight samples of symptomless leaves were randomly collected late in the growing season from a bacterial speck-infected tomato plot. As determined by Southern blotting with the COR15 DNA probe, the CFU/10 $\mathrm{g}$ of tissue for these eight samples was $3.0 \times 10^{1}$, $2.6 \times 10^{1}, 3.6 \times 10^{1}, 7.6 \times 10^{1}, 5.4 \times 10^{2}$, $1.3 \times 10^{5}, 1.5 \times 10^{5}$, and $1.6 \times 10^{5}$. Only those samples with at least $10^{5} \mathrm{CFU}$ per 10 g gave the expected 689-bp PCR product; the CFU/PCR for these three samples was $3.4 \times 10^{1}, 3.8 \times 10^{1}$, and $4.0 \times 10^{1}$. Thus, the detection limit/reaction for the leaf wash assay using field plants was similar to that obtained using squares of symptomless leaf tissue from inoculated plants grown in a protected environment. To be assured of a positive reaction, a 10-g leaf sample from field plants should contain at least $10^{5} \mathrm{CFU}$ of the target bacterium.

Effect of field plant age and the pathogen population size in lesions on PCR-based detection. As a field plant lesion ages, the $P$. syringae pv. tomato population in that lesion declines and other microorganisms establish themselves in the diseased tissue (13). We tested the effect of plant age on the PCR assay by randomly sampling lesions from the lower third of infected plants from grower fields in June (early, 37 days after planting), July (midseason, 59 days after planting), and August (just before harvest, 79 days after planting) (Fig. 2). The mean population size of the lesions sampled on those three dates was $6.57 \pm 0.56,6.72 \pm 0.58$, and $5.81 \pm 0.91 \quad$ (expressed as $\log _{10}$ CFU/lesion), respectively. The percentage of confirmed bacterial speck lesions that gave a positive PCR assay with the COR $1 / 2$ primers was 86,93 , and $70 \%$, respectively. Thus, a seasonal decline in the accuracy of lesion PCR corresponded to a decline in the mean lesion population of $P$. syringae pv. tomato.

Effectiveness of the COR1/2 and BSX1/2 PCR primer sets in disease diagnosis with greenhouse and field samples. Between 1997 and 2002, young lesion samples were collected from greenhouse- and field-grown tomato and pepper plants and assayed for the presence of $P$. syringae pv. tomato and BSX strains by a culture-based method and by PCRbased assays with primer sets COR $1 / 2$, BSX1/2, and RST 65/69. We isolated viable cells of $P$. syringae pv. tomato from 69 of the 70 bacterial speck-like lesions (from 70 different tomato fields) assayed. The COR $1 / 2$ PCR assay was negative for 2 of these 69 samples but positive for the 1 sample that was negative by the culturebased method. During this same period, we confirmed that bacterial spot-like lesions collected from 124 different greenhouses or grower fields contained viable BSX cells (Table 2). PCR with the RST primers produced an amplicon of the expected size (420 bp) for all 124 samples. However, the 579-bp amplicon expected with the BSX1/2 primers was produced for only $24.2 \%$ of the samples. Another $66.1 \%$ of the samples produced an amplicon of approximately $425 \mathrm{bp}$. Attempts to optimize the BSX1/2 PCR parameters did not change these results (data not shown). This 425-bp product hybridized to probes KK1750 and BSX1323, which was a DIGlabeled 1.32-kb fragment of KK1750, in dot blot analysis (data not shown). Restriction enzyme analysis of the RST amplicon
(31) of those strains producing the 425-bp BSX amplicon revealed that they were group D, or X. gardneri, strains (19). Like the Yugoslavian and Costa Rican $X$. gardneri strains, they were not amylolytic but weakly pectolytic (data not shown). The Ontario, Yugoslavian, and Costa Rican strains had identical rep-PCR fingerprints with primers BOX, ERIC, and REP (Fig. 3). Using restriction enzyme analysis of the RST amplicon, rep-PCR, and pectate/starch degradation assays, the remaining 12 BSX strains that did not produce the expected product with the BSX primers were identified as group $\mathrm{C}$ strains. All group C strains hybridized with probes BSX1323 and KK1750.

Analysis of the 425-bp BSX amplicon. All of the above PCR lesion assays had been performed with crude template DNA that had been prepared using the freeze-

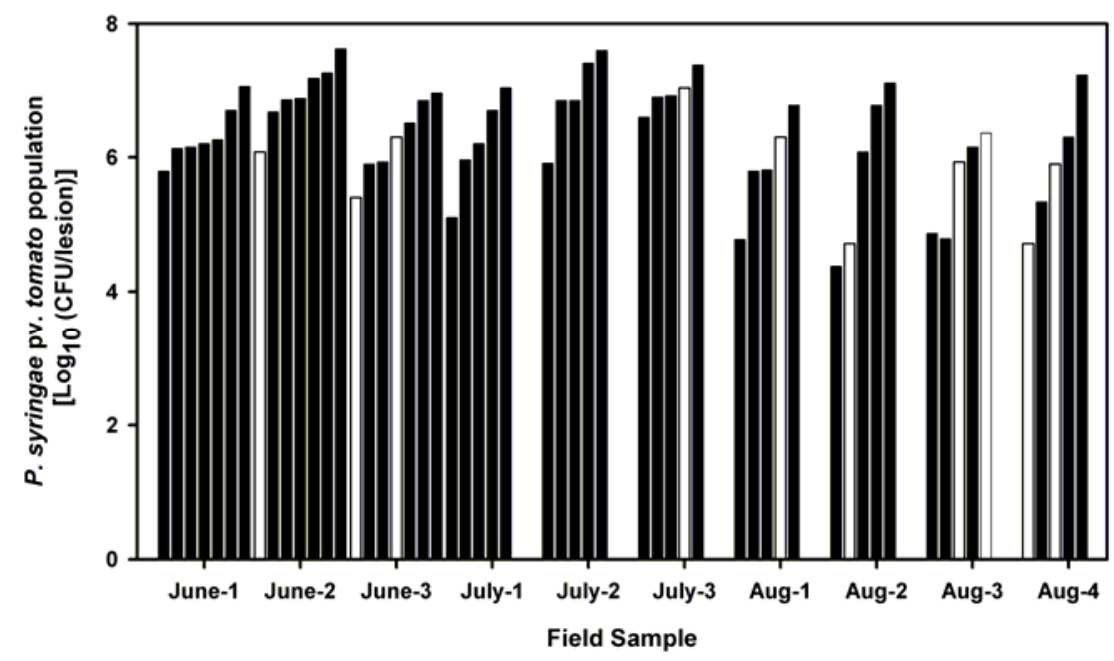

Fig. 2. Effect of field plant age and the Pseudomonas syringae pv. tomato population size in leaf lesions on polymerase chain reaction (PCR)-based detection of bacterial speck. Samples were collected from processing tomato grower fields in June (seven samples from each of three fields), July (five samples from each of three fields), and August (five samples from each of four fields). Each lesion was cut in half. One half was processed for PCR and the other half was used to determine the P. syringae pv. tomato population of the lesion as described previously (13). The 689-bp PCR product was visualized by subjecting $5 \mu \mathrm{l}$ of the reaction mixture to agarose gel electrophoresis. The identity of the PCR product was confirmed by a dot blot assay using the bacterial speck COR15 probe. Positive PCR assay for bacterial speck, black bar; negative PCR assay for bacterial speck, white bar.

Table 2. Frequency of polymerase chain reaction (PCR)-based detection of Ontario strains of the bacterial spot pathogen collected over a 6-year period using primer sets BSX1/2 and RST65/69

\begin{tabular}{lcccc}
\hline & & \multicolumn{2}{c}{ BSX PCR } & \\
\cline { 3 - 4 } Source & No. with pathogen $^{\mathbf{b}}$ & $\mathbf{5 7 9}$ bp & $\mathbf{4 5 0}$ bp & RST PCR \\
\hline 2002, Field & 13 & 0 & 10 & 13 \\
2001, Greenhouse & 2 & 0 & 0 & 2 \\
2001, Field & 10 & 6 & 1 & 10 \\
2000, Field & 70 & 4 & 63 & 70 \\
1999, Greenhouse & 3 & 2 & 0 & 3 \\
1999, Field & 4 & 0 & 3 & 4 \\
1998, Greenhouse & 6 & 6 & 0 & 6 \\
1998, Field & 5 & 1 & 5 & 5 \\
1997, Greenhouse & 4 & 7 & 0 & 4 \\
1997, Field & 7 & 30 & 0 & 7 \\
Total & 124 & & 82 & 124 \\
\hline
\end{tabular}

${ }^{\mathrm{a}}$ Each PCR assay was performed at least twice.

${ }^{b}$ Number of samples with confirmed pathogen. Bacteria that were isolated from these samples hybridized with the bacterial spot probe KK1750 and were pathogenic for tomato, pepper, or both. Hybridizations were performed at least twice for each strain. 
boil method of extraction. When PCR was performed using purified DNA from the BSX strains that previously had produced the 425-bp amplicon, a 579-bp amplicon that hybridized with probes KK1750 and BSX1323 was formed (data not shown). The PCR products generated with DNA from strain DC93-1 (group B) and the group D strains XCGA2 (type strain for 'X. gardneri'), DC00T7A, and DC99T6A, using crude extracts as template, were cloned into the vector pDrive using the Qiagen PCR Cloning Kit. These cloned fragments then were sequenced and compared (Fig. 4). The sequences of the ' $X$. gardneri' strains had $98.3 \%$ identity to each other but only $76.8 \%$ identity to $X$. vesicatoria DC93-1. The ' $X$. gardneri' sequences were missing a segment approximately $150 \mathrm{bp}$ in size located between nucleotides 270 and 420 of the strain DC93-1 sequence; otherwise, the sequences were almost identical.

\section{DISCUSSION}

Previous work has shown that coronatine production is an important trait for $P$. syringae pv. tomato, giving it a selective advantage in its natural habitat $(4,14,42)$. In fact, $P$. syringae pv. tomato strains that do not produce this toxin have not been unpublished data). Purified DNA extracts from $54 P$. syringae strains were used as templates in PCR assays with the coronatine primer set COR $1 / 2$ and only those isolated from Ontario tomato fields (14;

strains able to synthesize the toxin coronatine gave the expected 689-bp PCR product. These results are similar to those obtained with the PCR primer pair designed by Bereswill et al. and derived from the coronfacate ligase gene of the $P$. syringae pv. glycinea coronatine gene cluster $(5,29)$. However, our 6-year greenhouse and field study of the effectiveness of the COR1/2 PCR-based method for lesion identification is the first such study done for a PCR-based bacterial speck assay. It diverged from the culture-based method for only 3 of the 70 lesions tested. Thus, this assay, which has a reliability comparable to that of the conventional culturebased method, should provide the tomato industry with a rapid means of identifying bacterial speck lesions on transplants before these plants are transported to grower fields. It also should accelerate confirmation of disease diagnosis on field plants where symptoms often can be confused with those of bacterial spot or early blight (11).

In an earlier study, the BSX DNA probe KK1750, which hybridized to 46 of the 52 geographically diverse BSX strains assayed, had a weak response with 8 diverse, non-BSX, phytopathogenic xanthomonads from nonsolanaceous hosts (22). Subsequent sequencing of KK1750 (current study) and Southern blot hybridization has shown that the response of these non-BSX strains was due to a truncated transposase on one end of the sequence. Thus, the

\section{A}

\section{M123456 M1 23456 M 123456 M}

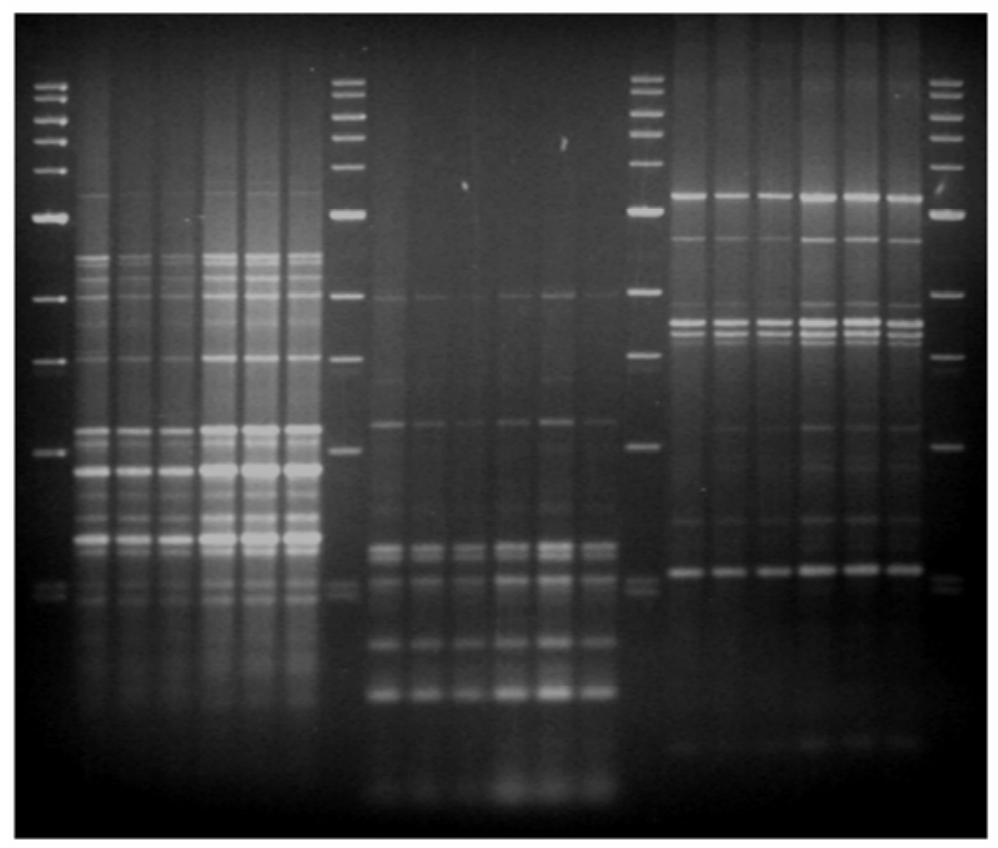

Fig. 3. Repetitive sequence-based polymerase chain reaction (rep-PCR) fingerprinting patterns generated for Xanthomonas gardneri strains and for recently isolated Ontario bacterial spot-causing xanthomonad (BSX) strains using primers A, BOX, B, ERIC, and C, REP. M, 1-kb ladder; lane 1, $X$. gardneri strain XCGA2; lane 2, X. gardneri strain Xv444; lane 3, X. gardneri strain Xv451; lane 4, Ontario strain DC99T6A; lane 5, Ontario strain DC00T58A; lane 6, Ontario strain DC01T46A. primers for our diagnostic work, BSX1/2, were selected from the other 1,300-bp portion of the sequence. This primer set amplified template DNA from strains belonging to all four BSX groups (Table 1). However, there were some BSX strains (8/37) in our geographically diverse collection that did not produce the expected 579-bp amplicon. All of these strains except for MSU1138, an unusual strain that belongs to group $\mathrm{D}$, hybridized to probe BSX1323; therefore, the lack of amplification may be due to sequence differences at the primer attachment sites. Single base mismatches may be sufficient to terminate primer extension during PCR (45). The RST65/69 primers produced a 420-bp product with template DNA from all 36 BSX strains; the 420-bp product also was generated with template DNA from 36 of 40 non-BSX xanthomonads included in the screening. The four nonBSX xanthomonads that did not respond to RST65/69 may have been missing a portion of the hrp gene cluster, but this possibility was not confirmed.

Under ideal conditions and with inhibitor-free template, the sensitivity of PCR assays can be as low as a few bacterial cells/reaction (15). However, when the template source is as complex as soil, biological waste, or plant material, the reaction easily can be inhibited by a number of substances, including complex polysaccharides, heavy metals, and humic acid $(2,45)$. A detection limit of 30 to $50 \mathrm{CFU} /$ reaction, as reported in this study, is optimal for PCR assays of plant tissue that do not include pre-enrichment or use a nested PCR approach $(6,18,43)$. The method used to extract DNA is critical. Incomplete lysis or the presence of polymerase inhibitors, as well as poor DNA yields, will reduce sensitivity. Myers et al. (28) reported that the PCR detection level for Vibrio parahaemolyticus in Gulf of Mexico water improved when samples were subjected to a simple boiling extraction method as opposed to a commercially available DNA purification kit. We made a similar discovery when working with infected tomato plant material (D. A. Cuppels, unpublished data) and, thus, DNA extractions were performed using a freeze-boil method with TTTE (35). To minimize the release of PCR inhibitors from diseased tissue samples, bacteria were eluted from the samples into water and harvested by centrifugation before being subjected to DNA extraction. Using this simple methodology, we found that a $25-\mathrm{mm}^{2}$ leaf sample from infected plants grown in a protected environment would have to have at least $4 \times 10^{3}$ to $1 \times$ $10^{4}$ BSX cells to give a positive PCR (40 to $100 \mathrm{CFU} /$ reaction). Previous work had shown that bacterial pathogen populations in tomato leaf lesions decline as the lesions age, but that even an old lesion ( 7 weeks old) averaged at least $10^{5} \mathrm{CFU}$ (13). In the present study, the mean population of bac- 
terial speck lesions randomly collected late in the season from the lower third of field tomato plants was $6.5 \times 10^{5} \mathrm{CFU}$, a 10 fold decline from the mean population observed in midseason; the percentage of positive COR1/2-PCRs declined as well, from 93 to $70 \%$. Plant leaves and lesions, as they age, attract opportunistic microbes that may block the availability of target DNA to the polymerase; they also may release more enzyme-inactivating substances (45). However, most samples submitted for disease diagnosis are taken from transplant seedlings or young, 4- to 6week-old field plants. In our 6-year study of the effectiveness of our PCR-based assay for the diagnosis of bacterial speck and bacterial spot, inhibitors were not a factor because there was $96 \%$ agreement between the COR1/2 PCR assay and the conventional culture-based assay and $100 \%$ agreement for the RST65/69 PCR assay and the culture-based assay.

Latent infections of apparently healthy greenhouse-grown seedlings or young field plants may provide an important inoculum source for bacterial speck and bacterial spot $(13,15)$. Thus, we modified our PCR protocol to one where freeze-boil DNA extraction was applied to bacteria collected by centrifugation from the wash water for 10 -g samples of symptomless, young seedlings. Samples containing $10^{5} \mathrm{CFU}$ of $P$. syringae pv. tomato (approximately 30 to $40 \mathrm{CFU} / \mathrm{PCR}$ ) gave a strong response with the COR $1 / 2$ primers, but samples with $5 \times$ $10^{2} \mathrm{CFU}$ or less did not. Unless the sensitivity of the assay can be improved through better DNA extraction or sampling methods, PCR may not be an effective means of screening symptomless tomato seedlings harboring low numbers of the target pathogen.

The BSX1/2 primer set for bacterial spot was not as effective in lesion diagnosis as the COR1/2 primer set for bacterial speck; $90 \%$ of the 124 bacterial spot lesions processed during the 6-year survey produced an amplicon with the BSX1/2 primers. The expected 579-bp amplification product was generated by only $27 \%$ of the BSX1/2positive samples; the remaining $73 \%$ had a 425-bp amplification product. Using repPCR fingerprinting, restriction enzyme

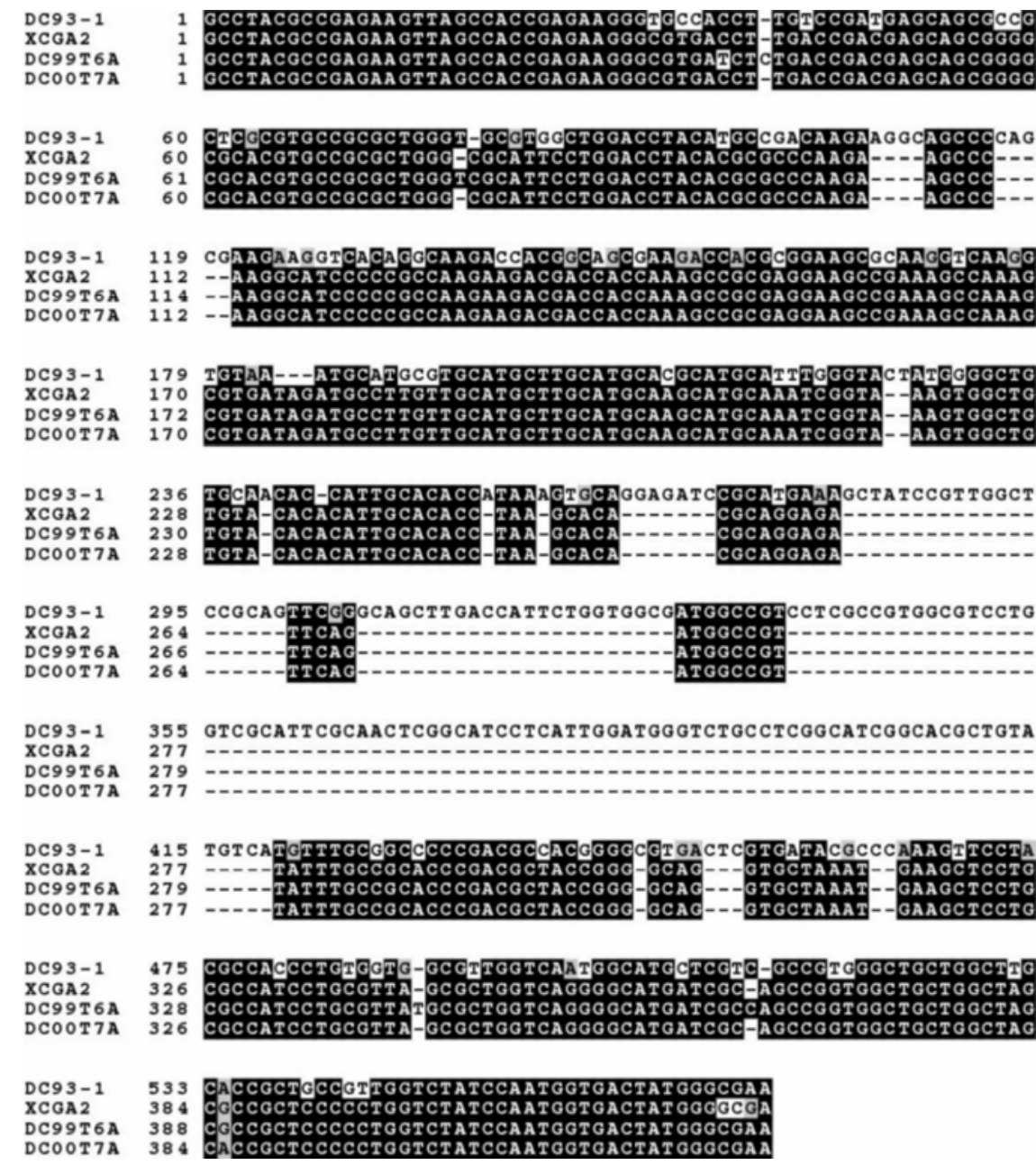

Fig. 4. Multiple alignment of the sequences of the amplicons generated using the BSX1/2 primers and DNA template from Xanthomonas vesicatoria strain DC93-1 (group B), X. gardneri strain XCGA2 (group D), Ontario strain DC00T-7A (group D), and Ontario strain DC99T6A (group D). The alignments were generated using CLUSTAL $V$ and the alignment output was formatted for printing using BOXSHADE version 3.21. Residues with a dark shading are identical. analysis of the RST65/69 amplification product (31), pectate and starch degradation assays, and pathogenicity tests, we confirmed that all BSX strains producing the 425-bp BSX1/2 product were group D or $X$. gardneri strains. When purified DNA from these strains was used as a PCR template, the BSX1/2 amplification product was the expected 579-bp sequence. The sequence of the 425-bp amplification product was almost identical to the 579-bp sequence, except that it was missing approximately $150 \mathrm{bp}$ from the middle of the sequence (Fig. 4). Differences in nucleoid proteins along the 579bp sequence between group D strains and strains of the other groups may explain these results (26). A nucleoid proteinDNA complex in this region of group D strains may have formed a loop that stays intact during the freeze-boil extraction but not during purification using a commercially available kit; in strains from the other BSX groups, this loop either may not be present or is released during both extraction processes. During PCR, the polymerase may not be able to replicate DNA that is in the loop portion of the segment, thus resulting in a 425-bp product. Additional experimentation is needed to test this hypothesis.

Group D strains were responsible for the bacterial spot epidemic that occurred in Ontario processing tomato fields in 2000 and predominated among the bacteria spot strains collected over the last 4 years. Of the 19 isolates collected in 2003 and 2004, 16 were $X$. gardneri strains (D. A. Cuppels and T. Ainsworth, unpublished data). This study is the first report of the widespread occurrence in a major tomato-growing area of North America of what had been considered a rare form of the bacterial spot pathogen $(7,19)$. However, a recent report indicates that group D strains now are present in Brazilian processing tomato fields (32). The origin of the Ontario group D strains is unknown. Very few studies of the bacterial spot pathogen have included group D strains. Our study also is the first report of group $\mathrm{C}$ strains occurring in tomato-growing regions of northern North America. Currently, our lab is determining the ecological fitness of group C and D strains under the environmental conditions found in southern Ontario.

Although the DNA fragment from which the bacterial spot primers BSX1/2 were derived has been sequenced, the functions of the open reading frames on this sequence are unknown. Because a sequence downstream of this region is homologous to a putative truncated transposase that is located in a region flanking the hrp gene cluster of $X$. axonopodis pv. vesicatoria 85-10 (30), the BSX1/2 template may be part of a pathogenicity island. Experiments designed to determine the exact genomic location of the KK17750 sequence are in progress. 


\section{LITERATURE CITED}

1. Altschul, S., Madden, T., Schaffer, A., Zhang, J., Zhang, Z., Miller, W., and Lipman, D. 1997. Gapped BLAST and PSI_BLAST: a new generation of protein database search programs. Nucleic Acids Res. 25:3389-3402.

2. Atlas, R., and Bej, A. K. 1994. Polymerase chain reaction. Pages 418-435 in: Methods in General and Molecular Bacteriology. P. Gerhardt, R. G. E. Murray, W. A. Wood, and N. R. Krieg, eds. American Society for Microbiology, Washington, DC

3. Ausubel, F. M., Brent, R., Kingston, R. E., Moore, D .D., Seidman, J.G., Smith, J. A., and Struhl, J. A., eds. 1987. Current Protocols in Molecular Biology, and Supplements. John Wiley \& Sons, Inc., New York.

4. Bender, C. L., Young, S. A., and Mitchell, R. E. 1991. Conservation of plasmid DNA sequences in coronatine-producing pathovars of Pseudomonas syringae. Appl. Environ. Microbiol. 57:993-999.

5. Bereswill, S., Bugert, P., Völksch, B., Ullrich, M., Bender, C., and Geider, K. 1994. Identification and relatedness of coronatine-producing Pseudomonas syringae pathovars by PCR analysis and sequence determination of the amplification products. Appl. Environ. Microbiol. 60:2924-2930.

6. Bereswill, S., Pahl, A., Bellemann, P., Zeller, W., and Geider, K. 1992. Sensitive and species-specific detection of Erwinia amylovora by polymerase chain reaction analysis. Appl. Environ. Microbiol. 58:3522-3526.

7. Bouzar, H., Jones, J. B., Stall, R. E., Hodge, N. C., Minsavage, G. V., Benedict, A. A., and Alvarez, A. M. 1994. Physiological, chemical, serological, and pathogenic analyses of a worldwide collection of Xanthomonas campestris pv. vesicatoria strains. Phytopathology 84:663671

8. Bouzar, H., Jones, J. B., Stall, R. E., Louws, F. J., Schneider, M., Rademaker, J. L. W., de Bruijn, F. J., and Jackson, L. E. 1999. Multiphasic taxonomy of bacteria causing spot disease on tomato and pepper plants in the Caribbean and Central America reveals distinct predominance of Xanthomonas axonopodis vesicatoria strains. Phytopathology 89:328-335.

9. Brooks, D. M., Hernandez-Guzman, G., Kloek, A. P., Alarcon-Chaidez, F., Sreedharan, A., Rangaswamy, V., Penaloza-Vazquez, A., Bender, C. L., and Kunkel, B. 2004. Identification and characterization of a well-defined series of coronatine biosynthetic mutants of Pseudomonas syringae pv. tomato DC3000. Mol. Plant-Microbe Interact. 17:162-174.

10. Cuppels, D. 1986. Generation and characterization of Tn5 insertion mutations in Pseudomonas syringae pv. tomato. Appl. Environ. Microbiol. 51:323-327.

11. Cuppels, D. 2001. Bacterial speck of tomato. Pages 82-83 in: Encyclopedia of Plant Pathology, 2-Vol. Set. O. Maloy and T. D. Murray, eds. John Wiley \& Sons, Inc., New York.

12. Cuppels, D. A., and Ainsworth, T. 1995. Comparison of the Pseudomonas syringae pv. tomato and Pseudomonas syringae pv. maculicola genetic loci required for the synthesis of the phytotoxin coronatine. Appl. Environ. Microbiol. 61:3530-3536

13. Cuppels, D. A., and Elmhirst, J. 1999. Disease development and changes in the natural Pseudomonas syringae pv. tomato populations on field tomato plants. Plant Dis. 83:759-764.

14. Cuppels, D. A., Moore, R. A., and Morris, V. L. 1990. Construction and use of a nonradioactive DNA hybridization probe for detection of Pseudomonas syringae pv. tomato on tomato plants. Appl. Environ. Microbiol. 56:17431749.
15. DeBoer, S., Cuppels, D. A., and Gitaitis, R. D. 1996. Detecting latent bacterial infections. Pages 27-57 in: Advances in Botanical research. S. DeBoer, J. Andrews, and I. C. Tommerup, eds. Academic Press, London.

16. Fenselau, S., Balbo, I., and Bonas, U. 1995 Sequence and expression analysis of the hrpB pathogenicity operon of Xanthomonas campestris pv. vesicatoria which encodes eight proteins with similarity to components of the Hrp, Ysc, Spa, and Fli secretion systems. Mol. Plant-Microbe Interact. 8:845-854.

17. Goode, M. J., and Sasser, M. 1980. Preventionthe key to controlling bacterial spot and bacterial speck of tomato. Plant Dis. 64:831-834.

18. Hartung, J. S., Daniel, J. F., and Pruvost, O. P. 1993. Detection of Xanthomonas campestris pv. citri by the polymerase chain reaction method. Appl. Environ. Microbiol. 59:11431148 .

19. Jones, J. B., Bouzar, H., Stall, R. E., Almira, E. C., Roberts, P. D., Bowen, B. W., Sudberry, J. Strickler, P. M., and Chun. J. 2000. Systematic analysis of xanthomonads (Xanthomonas spp.) associated with pepper and tomato lesions. Int. J. Syst. Evol. Microbiol. 50:1211-1219.

20. Jones, J. B., Lacy, G. H., Bouzar, H., Stall, R. E., and Schaad, N. W. 2004. Reclassification of the xanthomonads associated with bacterial spot disease of tomato and pepper. Syst. Appl. Microbiol. 27:755-762.

21. Jones, J. B., Stall, R. E., and Bouzar, H. 1998. Diversity among xanthomonads pathogenic on pepper and tomato. Annu. Rev. Phytopathol. $36: 41-58$

22. Kuflu, K., and Cuppels, D. 1997. Development of a diagnostic DNA probe for xanthomonads causing bacterial spot of peppers and tomatoes. Appl. Environ. Microbiol. 63:4462-4470.

23. Louws, F., and Cuppels, D. 2001. Molecular techniques. Pages 321-327 in: Laboratory Guide for Identification of Plant Pathogenic Bacteria. Third ed. N. W. Schaad, J. B. Jones, and W. Chun, eds. American Phytopathological Society Press, St. Paul, MN.

24. Louws, F., Fulbright, D. W., Stephens, C., and De Bruijn, F. J. 1995. Determination of genomic structure by rep-PCR fingerprinting to rapidly classify Xanthomonas campestris pv. vesicatoria. Phytopathology 85:528-536.

25. Louws, F. J., Wilson, M., Campbell, H. L., Cuppels, D. A., Jones, J. B., Shoemaker, P. B., Sahin F., and Miller, S. A. 2001. Field control of bacterial spot and bacterial speck of tomato using a plant activator. Plant Dis. 85:481-488.

26. McLeod, S. M., and Johnson, R. C. 2001. Control of transcription by nucleoid proteins. Curr. Opin. Microbiol. 4:152-159.

27. Morris, V. L., Jackson, D. P., Grattan, M., Ainsworth, T., and Cuppels, D. A. 1995. Isolation and sequence analysis of the Pseudomonas syringae pv. tomato gene encoding a 2,3diphosphoglycerate-independent phosphoglyceromutase. J. Bacteriol. 177:1727-1733.

28. Myers, M. L., Panicker, G., and Bej, A. K. 2003. PCR detection of a newly emerged pandemic Vibrio parahaemolyticus O3:K6 pathogen in pure cultures and seeded waters from the Gulf of Mexico. Appl. Environ. Microbiol. 69:2194-2200.

29. Nabizadeh-Ardekani, F., Koopmann, B., and Rudolph, K. 1997. The use of PCR to detect Pseudomonas syringae pv. tomato in planta. Pages 470-474 in: Pseudomonas syringae pathovars and related pathogens. K. Rudolph, T. Burr, J. Mansfield, D. Stead, A. Vivian, and J. von Kietzell, eds. Kluwer Academic Publishers, Dordrecht, The Netherlands.

30. Noël, L., Thieme, F., Nennstiel, D., and Bonas, U. 2002. Two novel type III-secreted proteins of Xanthomonas campestris pv. vesicatoria are encoded within the hrp pathogenicity island. J. Bacteriol. 184:1340-1348.

31. Obradovic, A., Mavridis, A., Rudolph, K. Janse, J. D., Arsenijevic, M., Jones, J. B., Minsavage, G. V., and Wang, J.-F. 2004. Characterization and PCR-based typing of Xanthomonas campestris pv. vesicatoria from pepper and tomatoes in Serbia. Eur. J. Plant Pathol. 110:285-292.

32. Quezado-Duval, A. 2004. Diversity of Xanthomonas sp. associated with bacterial spot of processing tomatoes in Brazil. (Abstr.) Page 52 in: 1st Int. Symp. Tomato Dis. 19th Annu. Tomato Dis. Workshop, Orlando, FL.

33. Rademaker, J. L. W., Louws, F. L., Schultz, M. H., Rossbach, U., Vauterin, L., Swings, J., and de Bruijn, F. J. 2005. A comprehensive species to strain taxonomic framework for Xanthomonas. Phytopathology 95:1098-1111.

34. Rangaswamy, V., Jiralerspong, S., Parry, R. and Bender, C. L. 1998. Biosynthesis of the Pseudomonas polyketide coronafacic acid required monofunctional and multifunctional polyketide synthease proteins. Proc. Natl. Acad. Sci. USA 95:15469-15474.

35. Reischl, U., Pulz, M., Ehret, W., and Wolf, H. 1994. PCR-based detection of mycobacteria in sputum samples using a simple and reliable DNA extraction protocol. BioTechnology 17:844-845

36. Sambrook, J., and Russell, D. W. 2001. Molecular Cloning: A Laboratory Manual, 3rd ed. Cold Spring Harbor Laboratory Press, Cold Spring Harbor, NY.

37. Schaad, N. W., Vidaver, A. K., Lacy, G. H., Rudolph, K., and Jones, J. B. 2000. Evaluation of proposed amended names of several pseudomonads and xanthomonads and recommendations. Phytopathology 90:208-213.

38. Sciaky, D., Montoya, A. L., and Chilton, M. D. 1978. Fingerprints of Agrobacterium Ti plasmids. Plasmid 1:238-253.

39. Short, J. M., Fernandez, J. M., Sorge, J. A., and Huse, W. D. 1988. $\lambda$ ZAP: A bacteriophage $\lambda$ expression vector with in vivo excision properties. Nucleic Acids Res. 16:7583-7600.

40. Sijam, K., Chang, C. J., and Gitaitis, R. D. 1991. An agar medium for the isolation and identification of Xanthomonas campestris pv. vesicatoria from seed. Phytopathology 81:831834.

41. Stall, R. E., Beaulieu, C., Egel, D., Hodge, N. C., Leite, R. P., Minsavage, G. V., Bouzar, H. Jones, J. B., Alvarez, A. M., and Benedict, A. A. 1994. Two genetically diverse groups of strains are included in Xanthomonas campes tris pv. vesicatoria. Int. J. Syst. Bacteriol 44:47-53

42. Ullrich, M., Bereswill, S., Völksch, B Fritsche, W., and Geider, K. 1993. Molecular characterization of field isolates of Pseudomoas syringae pv. glycinea differing in coronatine production. J. Gen. Microbiol 139:1927-1937.

43. Van Doorn, J., Hollinger, T. C., and Oudega, B. 2001. Analysis of the type IV fimbrialsubunit gene fimA of Xanthomonas hyacinthi: application in PCR-mediated detection of yellow disease in hyacinths. Appl. Environ. Microbiol. 67:598-607.

44. Vauterin, L., Hoste, B., Kersters, K., and Swings, J. 1995. Reclassification of Xanthomonas. Int. J. Syst. Bacteriol. 45:472-489.

45. Wilson, I. 1997. Inhibition and facilitation of nucleic acid amplification. Appl. Environ. Microbiol. 63:3741-3751.

46. Young, J. M., Bull, C. T., De Boer, S. H., Firrao, G., Gardan, L., Saddler, G. E., Stead, D. E., and Takikawa, Y. 2001. Classification, nomenclature, and plant pathogenic bacteriaa clarification. Phytopathology 91:617-620. 
ERRATUM

A change was made to this article on May 25, 2006. On page 453, column 2, under the subhead "PCR," the second sentence was corrected to read: The final $25-\mu$ reaction mixture contained $1 \times$ PCR buffer, $2.0 \mathrm{mM} \mathrm{MgCl} 2,0.2 \mathrm{mM}$ each dATP, dCTP, dGTP, and dTTP, $1 \mu \mathrm{M}$ each primer, and $0.63 \mathrm{U}$ of Taq polymerase (New England Biolabs, Ltd., Pickering, ON, Canada). 